\title{
Georeferenced Information System as a Tool in the Quantification of Protection Areas
}

\author{
F. L. B. Souza ${ }^{1}$, A. Feiden ${ }^{1}$, M. E. L. Rocha ${ }^{1}$, M. T. R. Abade $^{1}$, K. C. Milomes Junior ${ }^{2}$, P. W. R. Coutinho ${ }^{1}$, \\ D. P. Albuquerque ${ }^{2}$, M. T. Ávila ${ }^{2}$, I. L. C. Galdino ${ }^{1}$, J. S. Vorpagel ${ }^{1} \&$ F. S. Leite ${ }^{2}$ \\ ${ }^{1}$ Universidade Estadual do Oeste do Paraná, Campus Marechal Cândido Rondon, Brazil \\ ${ }^{2}$ Universidade Federal Rural da Amazônia, Campus Capitão Poço, Brazil \\ Correspondence: F. L. B. Souza, Universidade Estadual do Oeste do Paraná, Campus Marechal Cândido Rondon, \\ Centro de Ciências Agrárias Rua Pernambuco, 1777-Caixa Postal 91, Brazil. Tel: 55-045-3284-7916; \\ 55-045-3284-7918. E-mail: mylla-nanda@hotmail.com
}

Received: April 20, 2018

doi:10.5539/jas.v11n6p449
Accepted: March 19, 2019 Online Published: May 15, 2019

URL: https://doi.org/10.5539/jas.v11n6p449

\begin{abstract}
The use of georeferenced systems has been widely used to obtain data on the quality of the environment, aiming to quantify how areas are being occupied, and how natural reserves are being affected as a result of human action. The Sanga Mineira microbasin belongs to the Paraná basin 3 and is considered one of the main water reservoirs in the municipality of Mercedes, with 120 properties in its territory, whose main source of income is agriculture and livestock. For the expansion of monoculture areas, many areas of Legal Reserve and Permanent Preservation are being destroyed by farmers, causing a series of environmental imbalances. Thus, through the above, the research aimed to quantify the areas of Legal Reserve (RL) and Permanent Preservation Area (PPA) in the Sanga Mineira microbasin, using the Georeferenced Information System (GIS), in addition to detecting the main changes that occurred as a result of the change in the Forest Code, to assess whether the new laws have helped to improve the sustainability of the environment. Methodological technical procedures the SPRING program was used to evaluate 97 properties, of which the three main land use classes were verified: Permanent Preservation Area, Legal Reserve Area and Total Consolidated Area. It was concluded that there was a decrease in the Legal Reserve areas and an increase in the areas of APP's and Total Consolidated Area.
\end{abstract}

Keywords: legal reserve, microbasin, permanent preservation area, sustainability

\section{Introduction}

The increasing number of deforested areas in Brazil has generated great concern for environmentalists, mainly because it can generate environmental, social, economic and ecological imbalance in the environment. Among the main causes of deforestation are agricultural and livestock activities (Cardoso, 2006).

These changes in natural ecosystems have led to profound and probably irreversible changes in the Brazilian scenario (Almeida, 2000). According to the author, environmental degradation puts the planet at risk, generating problems such as drought, erosion, floods, disappearance of springs and rivers, resulting in the destruction of the original ecosystem.

Within the Brazilian legislation, the Forest Code bases the discussions regarding laws, resolutions and decrees related to environmental protection (Carvalho, 2016).

The first Brazilian Forest Code was established by Federal Decree No. 23,793, dated January 23, 1934. The legislation was in force until, with Federal Law No. 4,771, dated September 15, 1965, a new Brazilian Forest Code was established. Its latest version was launched in 2012, with law 12.651, dated March 25, 2012, complemented by law 12.727, October 2012 (Carvalho, 2016).

According to Law 12.651, which aims at sustainable development, Brazil is committed to the preservation of its forests and other forms of native vegetation, soil biodiversity, water resources and the integrity of the climate system, for the well-being of present and future generations (Brazil, 2012).

The new Forest Code establishes general rules on vegetation protection, Permanent Preservation areas and Legal Reserve areas, forest exploitation, supply of forest raw material, control of the origin of forest products and 
control and prevention of fires forestry, in addition to providing economic and financial instruments to achieve its objectives (Brazil, 2012).

According to the forest code chapter I, article 3, it is defined:

II: Permanent Preservation Area (PPA), protected area, covered or not by native vegetation, with the environmental function of preserving water resources, landscape, geological stability and biodiversity, facilitating the gene flow of fauna and flora, protecting and to ensure the well-being of human populations.

III: Legal Reserve: area located inside a rural property or possession, delimited in terms of art. 12, with the purpose of ensuring the sustainable economic use of the natural resources of the rural property, assisting the conservation and rehabilitation of ecological processes and promoting the conservation of biodiversity, as well as the shelter and protection of wildlife and native flora (Brazil, 2012).

The Forest Code provides differentiated ranges and parameters for the different typologies of PPAs, according to the characteristics of each area to be protected. In the case of the minimum ranges to be maintained and preserved on the banks of the watercourses (river, spring, lake or pond), the standard considers not only the conservation of vegetation, but also the characteristic and width of the course d ' water, regardless of location region, in either rural or urban areas (Schäffer, 2011).

The PPAs, together with the Legal Reserves (in the case of rural properties), with their protected vegetal cover, exert a buffer effect, reducing the drainage and transport of substances and elements to the bodies of water (Tundis et al., 2006).

Removal of vegetation in a forest environment leads, consequently, to erosive processes, which generate degradation of the environment and can spread to adjacent areas. Thus, declivity and vegetation cover become important factors in the decision making of an adequate management of the river basin, since they influence the effective precipitation, runoff and water flow in the soil (Cardoso et al., 2006).

Therefore, it is important that the adequate management of these basins be carried out in a coherent way, and a series of diagnoses must be elaborated, which should contain all the problems and the basin area history, identifying the conflicts and indicating the solutions in all levels, integrating conclusions and recommendations for the total recovery of the environment, resulting in the prognosis of the area (Silva \& Ramos, 2001).

Thus, through the above, the research aimed to quantify the legal reserve and permanent preservation areas in the Sanga Mineira microbasin, using the Georeferenced Information System (GIS), in addition to detecting the main changes that occurred as a result of the forest code change, to assess whether the new laws helped improve environmental sustainability by analyzing data for the years 2005 and 2017.

\section{Method}

The research is characterized as applied because it has the purpose of seeking solutions for the impacts caused by the change of the Forest Code, which has been affecting mainly the Legal Reserve and Permanent Preservation Areas in the Sanga Mineira microbasin in the municipality of Mercedes-Paraná, raising the question of how there can be a sustainable development in these areas, and their native forests are being taken to expand agroecosystems.

Regarding the problem approach, this is a qualitative and quantitative research, according to the methodology of Triviños (1994). Regarding the objectives, the research is defined as descriptive (Triviños, 1987). Regarding the procedures, in this work exploratory, descriptive and documentary studies were adopted.

For the delimitation of the research, data were used of 97 of the 120 properties in the hydrographic basin, since it was not possible to obtain the current data of 23 properties in the base used, but the sample was quite significant, since more than half of the existing properties were used in the microbasin. The microbasin is located in the municipality of Mercedes, West of the State of Paraná, latitude $24^{\circ} 09^{\prime} 04^{\prime \prime} \mathrm{W}$ and longitude $54^{\circ} 26^{\prime} 55^{\prime \prime} \mathrm{S}$, with an approximate elevation of 415 meters and a total area of 2058.59 ha. Figure 1 shows the location of the microbasin according to the DigitalGlobe images.

The information was obtained by means of already existing bases generated from the Basin Management Project of the Cultivating Good Water Program, carried out by Itaipu Binacional in the year 2005. For the conduction of this Program it was established that the microbasin should contain from 60 to 100 producers rural, a number considered adequate to be worked in rural extension processes, technical assistance and environmental education (Itaipu, 2018). 


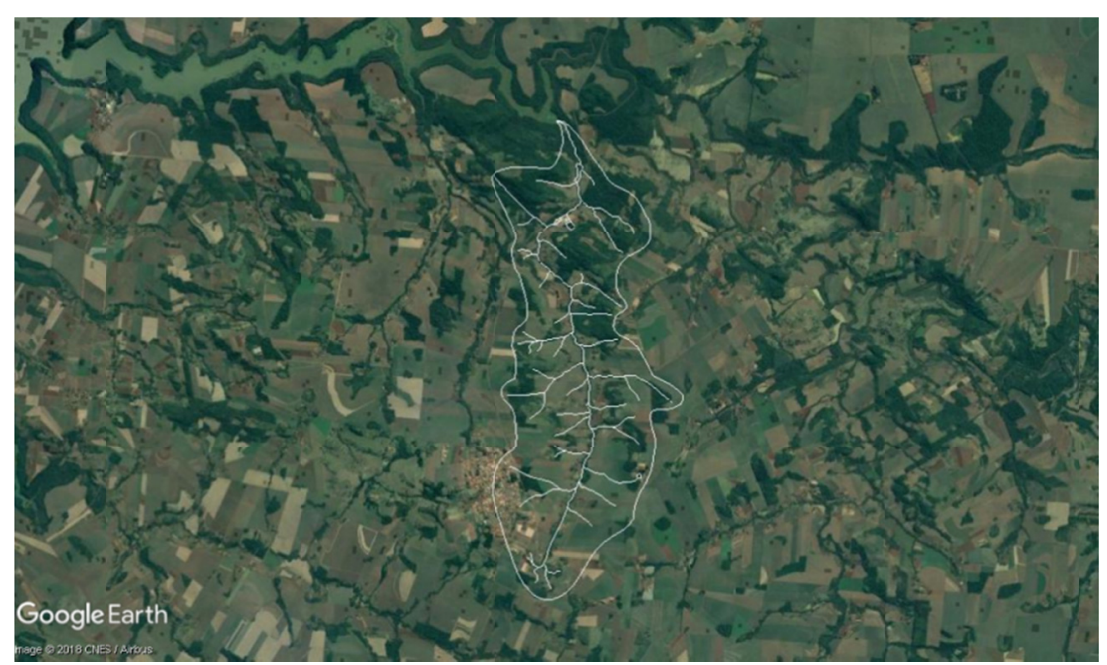

Figure 1. Location of the Sanga mineira microbasin-Mercedes, Paraná/2017

Source: DigitalGlobe.

Data were also acquired from the year 2017 of these properties, after the change of the Forest Code, in which changes occurred in the programs of data storage, when the Rural Environmental Registry-CAR was used. This database was obtained through the website of the National System of Rural Environmental Cadastre-SICAR, which contains information on properties of all Brazil.

For mapping and data processing, we used georeferenced information processing software, such as SPRING version 5.2.7, Qgis 1.8.0, using the Openlayers Google Earth plugin. Through these procedures it was possible to create maps in Qgis and tables and graphs in the Excel program.

From the SPRING software, it was possible to quantify land use classes, in which the following four types were identified: Permanent Preservation Area, Legal Reserve, Total Consolidated Area (resulting from the sum of the Consolidated Area of Agriculture, Pasture, Reforestation and Orchard) and Administrative Servitude.

In order to obtain the total area of each property and the amount that each class occupies within the total area, the class measures function was used. This process was carried out for the two legislations: the old one, based on the System of Maintenance, Recovery and Protection of the Legal Forest Reserve and Permanent Preservation Areas -SISLEG and the new one, using the bases of the National System of Rural Environmental Cadastre- SICAR, evaluating three situations, SISLEG diagnostic use, SISLEG designed use and CAR use; and were then compared to evaluate the differences that occurred within the area of the microbasin, looking at the situation that existed in 2005 and how the region is located in 2017.

\section{Results \& Discussion}

It was observed from the data obtained that the main class affected during these 12 years was the Legal Reserve area, which started to have 125.50 ha less native forest, as can be seen in Table 1 . In contrast, the class that obtained increase was the Total Consolidated Area, with 1122.41 ha with 177.46 ha more than area destined to agriculture, that is, the owners began to use the areas of Legal Reserve for agricultural purposes destroying the ecosystem there gift.

According to Ribeiro et al. (2005), this loss of forest cover directly affects the velocity and quantity of water that is drained, causing a superficial runoff, causing an increase of transport of materials into the rivers, causing erosive processes in the basins hydrographs.

This situation represented in Table 1 is due to the fact that, according to the new Forest Code, properties with up to four fiscal modules are exempt from having the $20 \%$ of Legal Reserve, not being necessary the reforestation of the same, being able to be counted only the existing quantity, if there is no Legal Reserve, there is no problem (Brazil, 2012). 
Table 1. Classes of soil use of the Sanga Mineira-Mercedes/Paraná watershed

\begin{tabular}{lll}
\hline Land Use Class & Old Forest Code (ha) & New Florest (ha) \\
\hline Permanent Preservation & 27.879579 & 67.726273 \\
Legal reserve & 308.634749 & 183.132998 \\
Total Consolidated Area & 944.950068 & 1122.408355 \\
Administrative Servitude & 10.829142 & 10.829142 \\
Total & 1292.293538 & 1384.096768 \\
\hline
\end{tabular}

Note. ha $=$ hectares.

Regarding the Permanent Preservation Areas (APP), there was an increase of 39.85 ha, because in 2005, they had areas near river basins and did not have APPs, were forced by law to recover them, since according to the legislation, using the SISLEG System, there was a period of 20 years for the reforestation of these areas.

According to the legislation of the time, properties that contain water resources had an obligation to preserve the riparian forests, which are responsible for maintaining a balanced environment. Among the main functions are: preserving water resources, landscape, facilitating the genetic flow of fauna and flora, protecting the soil and ensuring the well-being of human populations (Borges et al., 2011).

The law that determined the preservation and conservation of the areas, maintaining a minimum of $10 \%$ APPs, was only repealed in 2013, and the owners could not clear the Permanent Preservation Areas, considering that only those who had deforested until April 222008 and presented as reasons: public utility, social interest, agropastoral activities, ecotourism, rural tourism. If there were none of these reasons, the owners would be fined and forced to do the reforestation.

In the State of Paraná a fiscal module corresponds to 18.72 hectares. In the studied microbasin, property balances were performed to determine the amount of hectares that each property has inside the basin.

According to Table 2, of the 97 properties identified in the microbasin, in 2005, 73 were less than or equal to 1 fiscal module, totaling an area of 714.77 ha, while 22 properties had between 1 and 2 fiscal modules, corresponding to 511.96 ha and 2 properties between 2 and 3 modules, totaling 103.14 ha.

Table 2. Total properties in the Sanga Mineira-Mercedes/Pr microbasin

\begin{tabular}{|c|c|c|}
\hline Properties & 2005 & 2017 \\
\hline Size & $\mathrm{N}^{\mathrm{o}}$ Area (ha) & $\mathrm{N}^{\mathrm{o}}$ Area (ha) \\
\hline Less than or equal to 1 fiscal module & $73 \quad 714.767227$ & $69 \quad 676.89618$ \\
\hline Between 1 and 2 modules & $22 \quad 511.957614$ & $25 \quad 602.200915$ \\
\hline Between 2 and 3 modules & 103.141339 & 142.968894 \\
\hline
\end{tabular}

According to Wammes et al. (2007), there was a predominance of small properties in the Sanga Mineira microbasin in 2005 and the average area was 12.92 ha. The main activity in this period was agriculture and cattle ranching, and this factor may have contributed to the degradation of the Permanent Preservation areas, since small properties have the need of the maximum exploitation of the lands for the economic exploitation by means of the implantation of grazing areas near rivers, lakes and springs, causing in this way the environmental degradation of the APPs.

In 2017, it was verified that this situation of land division changed, being that the areas smaller or equal to 1 (one) fiscal module happened to be 69 , equivalent to 676.90 ha; already those between 1 and 2 fiscal modules increased to 25 properties, with an area of 602.20 ha and 3 properties with 142.97 ha between 2 (two) and 3 (three) modules.

What may justify this increase is the fact that some owners have bought areas to expand their own, and now, with the new data cadastre system, properties that belong to the same owner must be added as one.

Figure 2 represents the existing scenario in the watershed in 2017, the colors were used to distinguish the size of the properties. In light yellow are the areas of up to 1 fiscal module, yellow canary areas between 1 and 2 fiscal modules and burnt yellow are properties between 2 and 3 fiscal modules. 


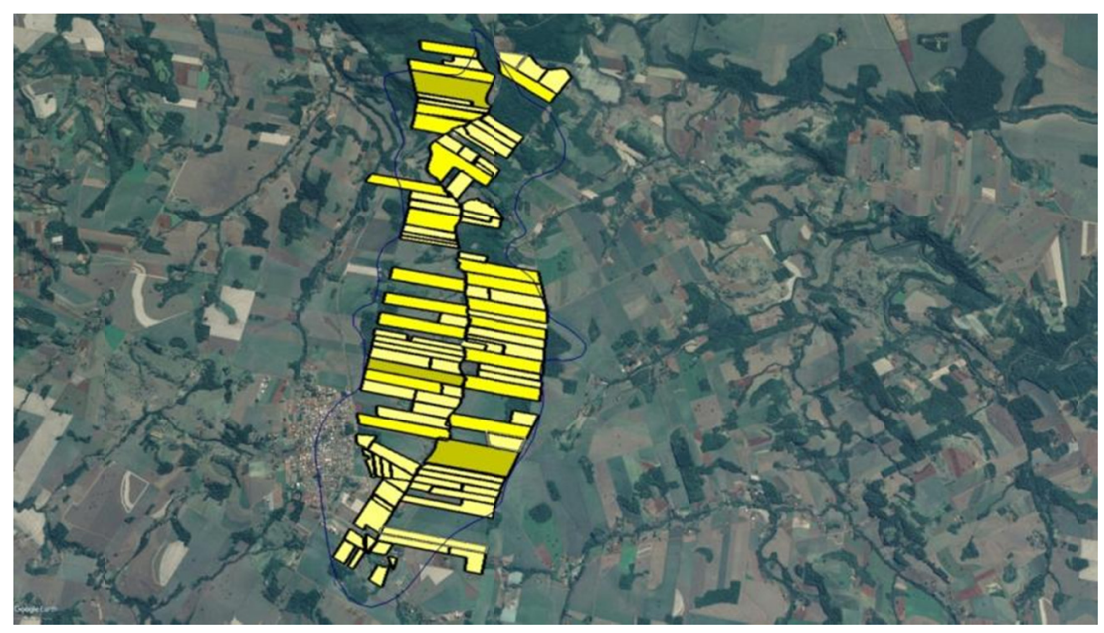

Figure 2. Mosaic of the rural properties located in Sanga Mineira

Source: DigitalGlobe.

Figure 3 reproduces the difference in percentage of the 3 main classes studied and it can be verified how the microbasin was affected with the changes in the Brazilian legislation.

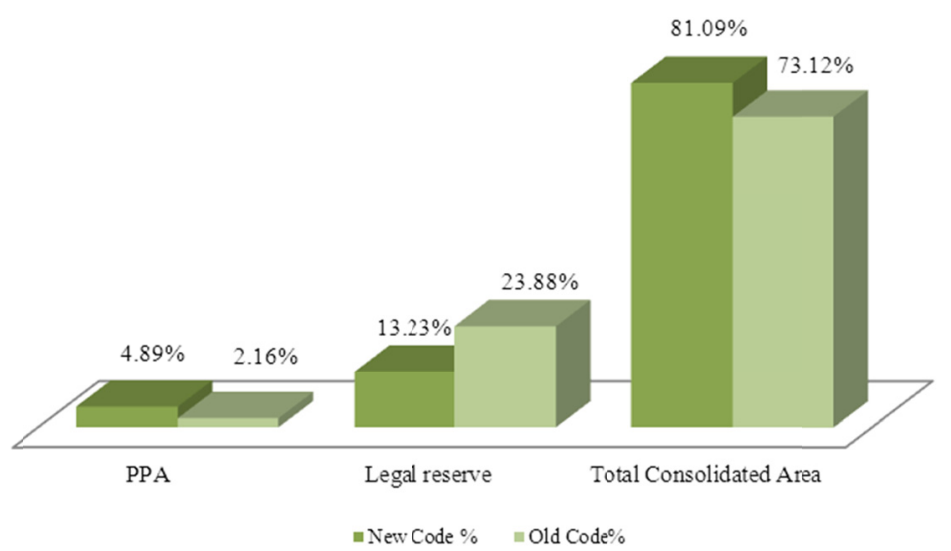

Figure 3. Changes in the properties of the Sanga Mineira watershed, due to the change in legislation

With the new Forest Code, the Permanent Preservation areas increased by more than 2\% from 2005 to 2017, becoming $4.89 \%$ in all watershed territory, while the Legal Reserve area was the one that suffered most from the new Forestry Code, presenting a loss of approximately $10 \%$ in the area that was previously destined for the conservation of natural resources, the current value of this class is $13.23 \%$.

At the same time, in the Consolidated Total Area there was an increase of $7.97 \%$ in the percentage, that is, the area that was previously destined to the Legal Reserve was converted into Total Consolidated Area.

According to Dill (2007), most watersheds are being inadequately occupied, an area that should be protected because of natural resources, and is used for the implantation of monocultures. This has generated a number of problems, such as the deterioration of natural resources (Water Resources, Fauna, Soils and Air).

Despite the increase in the area of Permanent Preservation, this value in hectares is still very small when compared to the Total Consolidated Area, demonstrating that producers have a greater concern with production than with the preservation of natural resources for future generations. It becomes worrying how the environment is treated by many farmers who aim only for profit rather than the well being of society, these types of practices have caused a number of environmental problems, mainly to the soil.

According to Skorupa (2003), the Permanent Preservation Areas are of fundamental importance for sustainable rural development, since it is possible to point out a series of environmental benefits resulting from the 
maintenance of these areas. According to the author, in these cases, these benefits can be analyzed in two aspects: the first one regarding the importance of PPAs as physical components of the agroecosystem and the second with respect to the ecological services provided by the existing flora.

In Figure 4 an overview of the microbasin and the properties that are part of it, evidencing the areas of Permanent Preservation, Legal Reserve, Consolidated Agricultural Area and Administrative Servitude. There is a predominance of yellow areas which, according to the legend, refers to the consolidated agricultural area and it is clear that many of the properties studied do not have Legal Reserve area, being identified by the green coloration in the legend. The lack of vegetation causes many damages to these areas near the basins, because these are very sensitive to any ecological imbalance.

According to Souza and Fernandes (2000), river basins are ideal ecosystems for the evaluation of environmental impacts, since they are sensitive to any change in their original structure, causing damage to the balance and maintenance of water quantity and quality, since these variables are related to the use of the soil, which ends up directly affecting the living beings, since they need quality water to have a healthy life.

Silva (2007) complements the fact that despite the man's need for good natural resources, it is possible to identify that most environmental problems are the result of human interventions in the development of rural activities, especially environmental resources. Therefore, the hydrographic basins are taken as a reference in the planning and development of actions of spatial organization, implementation of individual and collective infrastructure and environmental preservation.

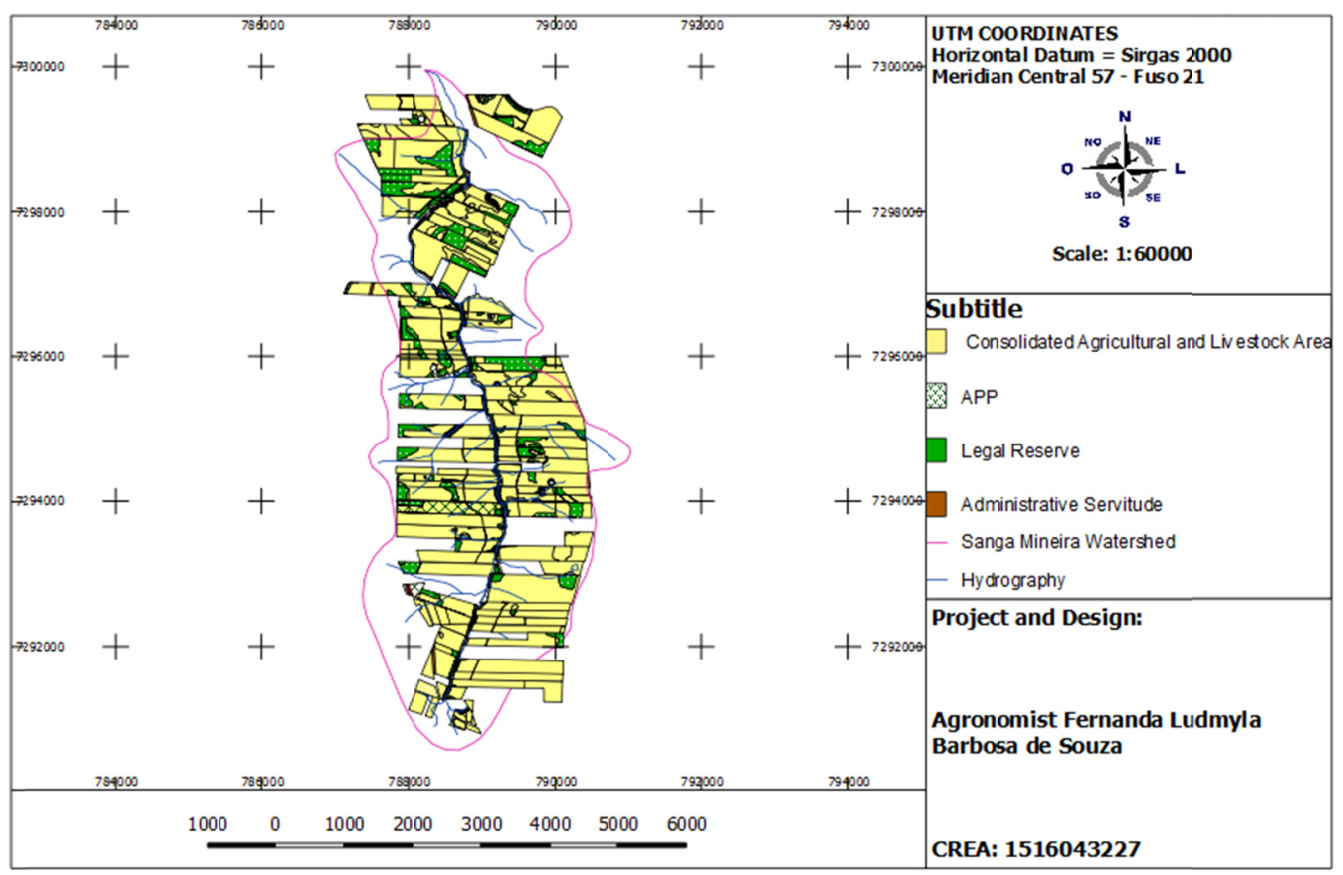

Figure 4. Map of the current situation of the Sanga Mineira watershed properties-2017

The State of Paraná was one of the few states in Brazil that had a specific environmental legislation, aiming at the recovery of native areas, as well as making landowners comply with legal requirements. One of the reasons that led to the creation of this system was the fact that the state was one of the most affected by the deforestation of areas for implementation of agricultural activities and non-compliance with the Forest Code.

The system of maintenance, recovery and protection of the Legal Forest Reserve and Permanent Preservation Areas (SISLEG) was created in 1999, in the State of Paraná, in order to make the State have an index of at least $20 \%$ of vegetation cover (Paraná, 1999). The same was revoked in 2013, being replaced legally by SICAR.

Figure 5 shows the number of PPAs in Sanga Mineira, where three occasions are observed: the first shows the amount of PPA's in the microbasin in 2005, the second the amount of PPA's that should be restored according to the diagnosis and with the law established by SISLEG and the third the existing PPA area in 2017 after all the changes that have occurred in the Forest Code. 
It is noted that in 2005 there were 27.88 ha of APP's in the whole area of the microbasin, this data was established based on the diagnosis made by the Project for the Basins of the Program Cultivating Good Water of Itaipu Binacional. This program was created with the purpose of conserving natural resources and biodiversity, providing a better quality of life for the communities of the Paraná river basin 3 (Itaipu, 2018).

From this project, several areas belonging to the Paraná Basin 3 were diagnosed to estimate the number of existing APP's and Legal Reserve areas that needed to be restored in accordance with current legislation.

After the diagnosis was designed to the amount of area that should be restored using the System of Maintenance, Recovery and Protection of the Legal Forest Reserve and Areas of Permanent Preservation as a base, this system belonging to the State of Paraná.

It was determined that the restored area should be 34.53 ha, adjusted depending on the need for each property, always taking into account the ranges defined in the Brazilian Forest Code of 1965, establishing a term of up to 20 years for the recovery of these areas, should remain with 62.41 ha of environmental protection area after recovery.

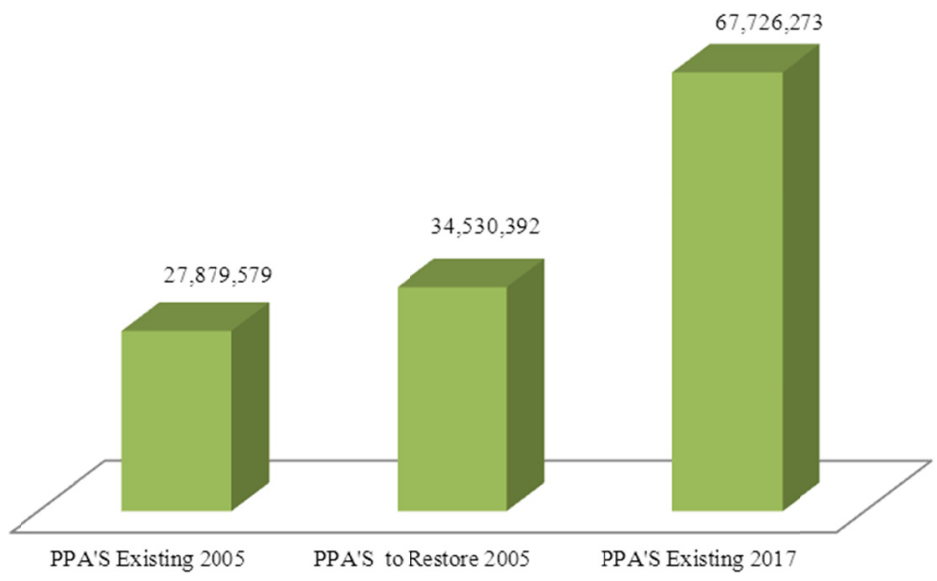

Figure 5. PPA quantification in the Sanga Mineira microbasin

Regarding the data collection of the existing situation in 2017, it is noticed that the area increased considerably, exceeding what had been predicted in the SISLEG project, the area presented $67.73 \mathrm{ha}$, regardless of the change of Forest Code and the new system defined in 2012, the CAR. As of 2012 and according to the new legislation, Permanent Preservation Areas around rivers and streams should be defined according to the size of the property (Brazil, 2012).

In accordance with the work developed by Nascimento (2015), in the Sanga Baitaca microbasin, an area of 38.74 ha of APP's area around the rivers was obtained, and it was necessary to restore 28.35 ha to stay within the $10 \%$ required by the former Forest Code.

The similarities between the two micro-basins that are in the Paraná basin 3 are visible, both of which present similar proportions of PPA's areas. However, the Sanga Baitaca microbasin required a smaller area of restoration, this may be a peculiar characteristic of the properties belonging to the Paraná basin 3 , because, based on some studies done on properties in the region, rural farmers have small areas tend to use the maximum of the same and with this end up destroying the native forests.

According to Silva (2006), part of the existing difficulties regarding the real preservation of PPAs is due to the fact that environmental legislation uses the same criteria for the whole country when it is known that Brazilian ecosystems are very different, varying from region for region, including significant variations in relief.

The same process was carried out in relation to the Legal Reserve areas and in Figure 6 are the three situations, Legal Reserve existing in 2005, Legal Reserve to restore 2005 and Legal Reserve existing in 2017. According to the data obtained, it was found that the existing Legal Reserve area at the time was equivalent to 308.64 ha, which was not yet within the total required by law and, according to the legislation of Paraná, it would still be necessary to restore $110.41 \mathrm{ha}$, total Legal Reserve of 419.04 ha. 


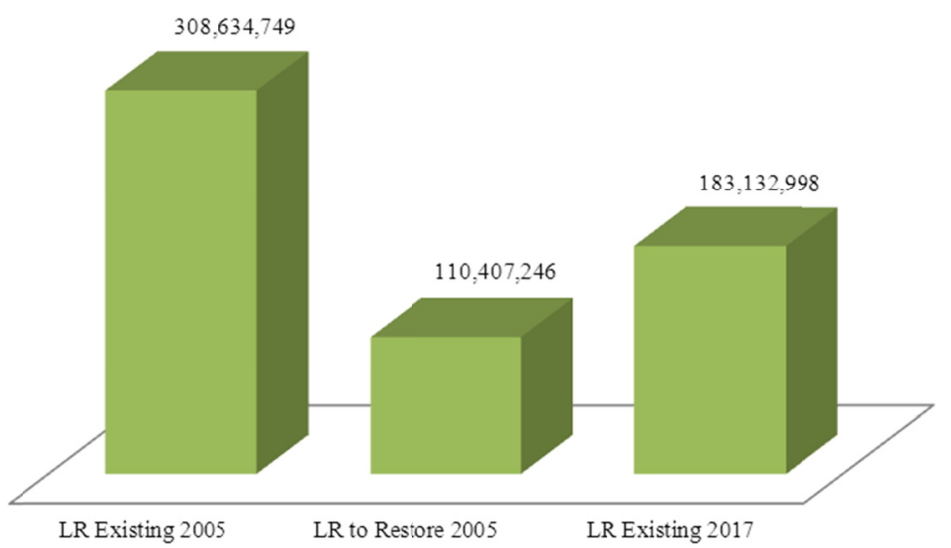

Figure 6. Quantification of legal reserve areas in the Sanga Mineira watershed

Note. $\mathrm{RL}=$ Legal reserve.

With the repeal of existing legislation at the time and the change of cadastral system, it is observed that the values had a sudden reduction, showing a total area of 183.13 ha in each microbasin.

These massive destructions cause serious damage to the flora and fauna of the place, as a series of fragments occur in the environment, causing many animals to be left without habitats, besides interfering directly in the quality of the water, because the vegetation serves as protection and aid in the infiltration of water into the soil. According to Rambaldi and Oliveira (2003), ecosystem changes generate the loss of many services with deleterious consequences in the medium and long term. Some are clearly visible in Brazil, such as the decline in inland fish stocks and changes in water regimes.

Figure 7 shows how the Legal Reserve amounts are distributed in the properties of the Sanga Mineira microbasin in 2017, among the 97 properties diagnosed $69 \%$ of these had a decrease in the area allocated to Legal Reserve, $6 \%$ remained with the same area that had in $2005,18 \%$ had an increase and $7 \%$ of the properties did not present any area of Legal Reserve, that is, within the area sampled there are properties that totally exterminated its Legal Reserve, which should not have happened if the old Forest Code was in force. On the contrary, these landowners would be obliged to recover those areas, in addition to paying fines for non-compliance with the law.

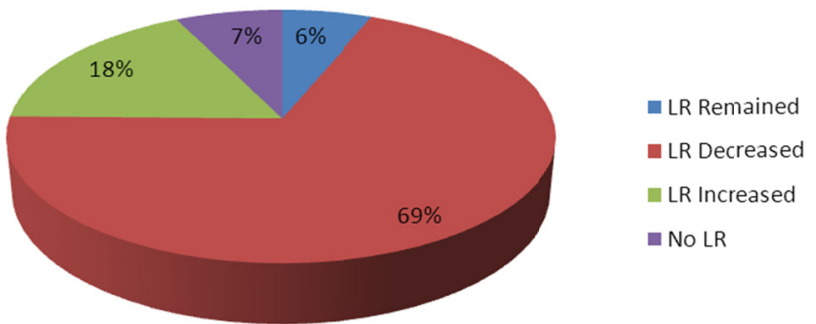

Figure 7. Proportions of existing legal reserve areas in the Sanga Mineira microbasin

Figure 8 shows the percentage distribution of existing APP areas in the Sanga Mineira microbasin, with $6 \%$ of properties showing the same amount of Permanent Preservation area that they had in 2005, 24\% of which decreased their APP, $60 \%$ an increase and $10 \%$ of the properties did not present Permanent Preservation Area. This means that even with the increase in the percentage of Permanent Preservation Area, as seen in the figures above, there are still properties that completely destroyed their APP areas, which should be punished by law, as there are many damages that these $10 \%$ of properties without riparian forest may be causing within the river basin. 


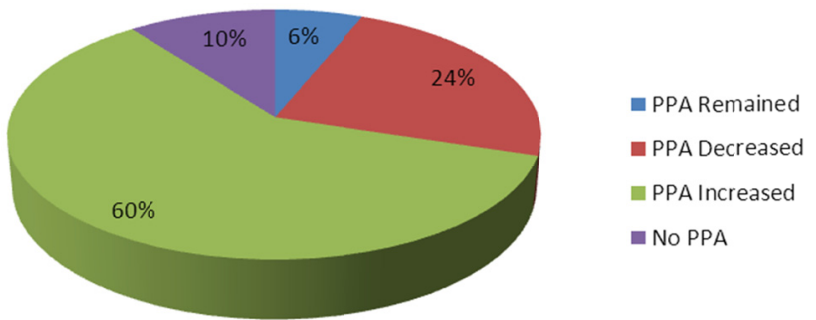

Figure 8. Percentage of permanent preservation areas in the sanga mine microbasin

According to Ribeiro et al. (2005), the lack of official demarcation of the areas of the PPAs is one of the factors that facilitate the noncompliance with the legislation that created them, leading to the occupation and illegal use of these areas.

Coutinho et al. (2013), conducting a survey in the Rio de la Plata river basin, observed that $50.40 \%$ of the sub-basin APPs were being used for economic or occupational purposes, contrary to environmental legislation. Of these, agricultural activities-permanent and temporary-occupy $27.07 \%$, followed by pastures-clean and dirty-occupying $22.52 \%$. The areas of exposed soil and urban area have the lowest occupancy rates, in descending order.

This fact demonstrates that it is not only in the State of Paraná that the neglect and undue concern with the APP's areas occur, which is worrying because of the importance of these areas to the Planet.

Figure 9 shows the percentage of real estate size in properties, with three circumstances: the area of real estate that remained the same in those 12 years, the area of real estate that decreased over the evaluation periods and the area of real estate that increased. It is observed that $49 \%$ of the properties remained the same size during those 12 years, $17 \%$ had their area decreased and $34 \%$ increased.

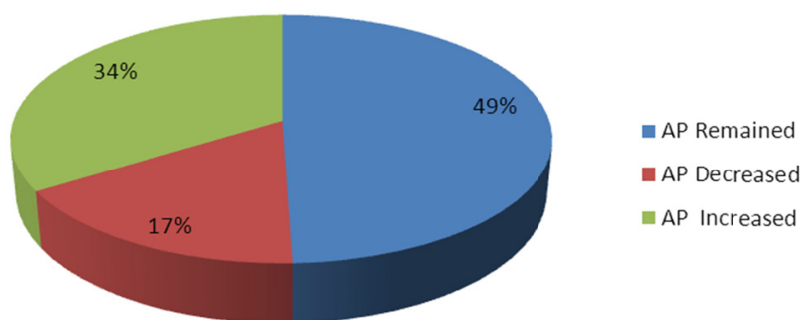

Figure 9. Relation of real estate areas

Note. AP $=$ Area of the Property.

Figure 10 shows the percentage of Consolidated area present in the properties, among the 97 studied $25 \%$ remained with the same area they had in $2005,22 \%$ had a Consolidated area reduction and $54 \%$ of properties increased their areas, implying that there was an increase in agricultural production, being justified because there was a decrease in mass of the Legal Reserve areas in the Sanga Mineira microbasin.

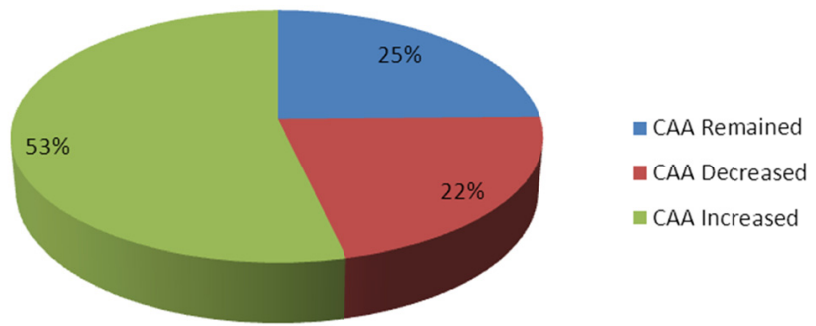

Figure 10. Relation of the areas of consolidated agriculture

Note. $\mathrm{CAA}=$ Consolidated Agricultural Area. 
One can say that there has been a setback in relation to the old legislation, since it is clearly seen that the areas of permanent preservation and legal reserve are of inestimable importance in relation to the equilibrium of a microbasin. A development that does not take into account the ecosystem of a place, can not be defined as sustainable, as opposed to sustainable it is a delay for society.

However, the CAR brought some benefits, such as the registration of all rural properties for greater control of the amount of each existing area, since not all the states that had a specific legislation and database of their municipalities, such as Paraná. But this is not enough, it is important to think of laws that help maintain the areas of permanent preservation and legal reserve, only in this way will there be a balanced environment and especially that seeks a development with sustainability.

\section{Conclusion}

The study provided a comprehensive overview of the changes that have occurred in the last 12 years, mainly due to changes in legislation. Highlighting important items related to the development of the Sanga Mineira microbasin, it was observed that, with the changes made in the Forest Code, producers started to occupy their areas as much as possible, utilizing previously preserved areas.

Among the 97 properties, there was a predominance of small properties, which showed an increase in the number of APPs, reaching an area of 67.73 ha, presenting $4.89 \%$ in the total area of the basin. However, there was a decrease in the Legal Reserve area which exhibited an area of 183.13 ha, $13.23 \%$.

The Total Consolidated Area also expanded, reaching $81.09 \%$ of the total area of the watershed.

\section{References}

Almeida, D. S. (2000). Environmental Recovery of the Atlantic Forest (p. 130). Ilhéus: Editus.

Borges, L.A. C., Rezende, J. L. P., Pereira, J. A. A., Junior Rabbit. M. L., \& Barros, D. A. (2011). Areas of permanent preservation in Brazilian environmental legislation. Rural Science, 41(7), 1202-1210. https://doi.org/10.1590/S0103-84782011000700016

Brazil. (2012). Law no. 12.651, of May 25, 2012. New Forest Code. Provides for the protection of native vegetation; amends Laws 6,938 of August 31, 1981, 9,393 of December 19, 1996, and 11,428 of December 22, 2006; revokes Laws Nos. 4,771, September 15, 1965, and 7,754, April 14, 1989, and Provisional Measure No. 2,166-67 of August 24, 2001; and makes other arrangements. Official Journal of the Federative Republic of Brazil.

Cardoso, C. A., Dias, H. C. T., Soareas, C. P. B., \& Martins, S. V. (2006). Morphometric characterization of the Debossan river basin, Nova Friburgo, RJ. Revista Árvore, 30(2). https://doi.org/10.1590/S0100-6762 2006000200011

Carvalho, E. B. de. (2016). The Brazilian Forest Code of 1934: the forest legislation in the disputes over the territory, a case study 1990s. Porto Alegre, 23(43), 417-442.

Castagnara, D. D., Uhlein, A., Feiden, A., Wammes, E. V. S., Perini, L. J., Stern, E., ... Silva, N. L. S. (2007). Environmental importance of legal reserve areas and their quantification in the Sanga Mineira watershed of the municipality of Mercedes-PR. Brazilian Journal of Agroecology, 2(2).

Coutinho, L. M., Zanetti, S. S., Cecily, R. A., Garcia, G. G. de O., \& Xavier, A. C. (2013). Land Uses and Areas of Permanent Preservation (APP) in the Rio de la Plata Basin, Castelo-ES. Forest and Environment, 20(4), 425-434.

Dill, P. R. J. (2007). Environmental management in river basins (Thesis (Doctorate in Agricultural Engineering), Federal University of Santa Maria, Santa Maria).

Fonseca, J. J. S. (2002). Methodology of scientific research. Fortaleza: UEC, Apostila.

Gerhardt, T. E., \& Silveira, D. T. (2009). Research Methods (p. 120). Porto Alegre: da Ufrgs.

IBGE (Brazilian Institute of Geography and Statistics). (2018). Geodesy. Retrieved from https://ww2.ibge.gov. $\mathrm{br} /$ home/geociencias/geodesia/pmrg/faq.shtm

Itaipu. (2018). Cultivating good water. Retrieved from https://www.itaipu.gov.br/meioambiente/cultivandoagua-boa

Nascimento, E. V. J. do. (2015). Impacts of the new brazilian forest code in protected areas of vegetation protected by law in the microbacy of sanga baitaca in the municipality of Marechal Cândido Rondon PR (55f., 
Dissertation (Postgraduate in Sustainable Rural Development), State University of the West of Paraná, Marechal Cândido Rondon).

Paraná. (1999). State Decree 387 of March 3, 1999. Establishes the System for the Maintenance, Recovery and Protection of the Legal Forest Reserve and Permanent Preservation Areas, integrated to the Paraná Conservation Program. Biodiversity (Biodiversity Network), State Forestry Mandatory Replenishment System (SERFLOR), State Forest Development Program (PRODEFLOR) and Municipal Forests Program. Official Journal of the State of Paraná.

Rambaldi, D. M., \& Oliveira, D. A. S. (2003). Ecosystem Fragmentation: Causes, Effects on Biodiversity and Public Policy Recommendations (p. 510). Brasília: MMA/SBF.

Ribeiro, C. A. A. S., Soares, V. P., Oliveira, M. A. S., \& Gleriani, J. M. (2005). The challenge of delimiting areas of permanent preservation. Revista Árvore, 29(2), 203-212. https://doi.org/10.1590/S0100-6762200500 0200004

Rodrigues, F. M., Pissarra, T. C. T., \& Campos, S. (2008). Morphometric characterization of the hydrographic microbasin of the Glória farm stream, Municipality of Taquaritinga, São Paulo. Irriga, 13(3), $310-322$. https://doi.org/10.15809/irriga.2008v13n3p310-322

Schäffer, W. B. (2011). Areas of permanent preservation and conservation units X risk areas: What has one thing to do with the other? (p. 99). MMA, Brasília.

Silva, D. D., \& Ramos, M. M. (2001). Planning and integrated management of water resources. Brasília: ABEAS; Viçosa: UFV/DEA.

Silva, N. L. S. (2007). Study of sustainability and rural development indicators (p. 271, Thesis (Graduate in Agronomy, area of concentration in Plant Production), State University of Maringá, Maringá).

Skorupa, L. A. (2003). Areas of Permanent Preservation and Sustainable Development. Jaguariúna, Embrapa Meio Ambiente.

Souza, E. R. de, \& Fernandes, M. R. (2000). Hydrographic sub-basins: basic units for the sustainable planning and management of rural activities. Agricultural Report: Microbasin Management (Vol. 21, p. 207). Belo Horizonte: Líthera Maciel.

Triviños, A. N. S. (1987). Introduction to research in social sciences: Qualitative research in education (p. 175). São Paulo, Atlas.

Triviños, A. N. S. (1994). Introduction to Research in Social Sciences. São Paulo: Atlas.

Tundisi, J. G. (2006). Eutrophication in South America: Causes, management and control technologies (p. 531). IIE, Iiega, IAP, Ianas, ABC.

Wammes, E. V. S., Uhlein, A., Castagnara, D. D., Feiden, A., Perini, L. J., Stern, E., ... Silva, N. L. S. (2007). Environmental importance of permanent preservation areas and their quantification in the Sanga Mineira watershed of the municipality of Mercedes-PR. Summaries of V CBA-Use and Conservation of Natural Resources. Brazilian Journal of Agroecology, 2(2).

\section{Copyrights}

Copyright for this article is retained by the author(s), with first publication rights granted to the journal.

This is an open-access article distributed under the terms and conditions of the Creative Commons Attribution license (http://creativecommons.org/licenses/by/4.0/). 